\title{
MODIFICATION OF THE SLOVENIAN COMPANIES ACT AND IMPROVEMENT OF CORPORATE GOOD PRACTISE
}

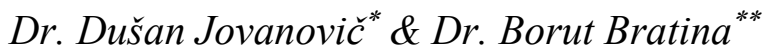

Before summer 2015, the Slovenian legislator has again amended the Companies Act and has, by adopting the amendment ZGD-1I (107 articles), introduced important modifications that also effect the execution and development of corporate governance. The amendment itself was being drafted for as long as three years and thus presents an expertly prepared proposition of needed modifications to the corporate legislation, however, in the final phase of adoption and execution, the document became subject to political synchronization once again, which resulted in paramount corporate institutions, including the regulations on the dormant partnership and the formulation of the judicially recognized Business Judgement Rule, to be left out of the reform. Nevertheless, the amendment ZGD-1I still includes a number of novelties that have a decisive impact on the corporate governance. Amongst the most important are the layout of D\&O Insurance, limitation period for the waiver of compensation claims against the members of the management and supervisory bodies and a more detailed organization of the audit committee, especially as regards particular openended questions that have their origin in the corporate governance practice and address the relations between the management and supervisory bodies. Newly introduced is also the institution of internal audit, where the solutions are optional, except for the companies, which have to arrange the internal audit pursuant to other laws (e.g. pursuant to the Banking Act and the Insurance Act). Amongst the significant modifications to the corporate legislation are also the completely changed provisions on minor offences that have an important influence on corporate governance and on the operation of the management and supervisory bodies. In the article, the authors present the modified corporate law solutions that have a material impact on corporate governance into details, while delivering their critical view on the modifications and offering propositions for possible enhancement of corporate governance in Slovenia.

INTRODUCTION

I. AMENDMENT ZGD-1I.

\footnotetext{
* Assoc. Prof. Dr. Dušan Jovanovič, Institution/Affiliation: Faculty of Economics and Business, University of Maribor. Research fields: Corporate Law, Corporate Governance, Business Law, Tax Law.

${ }^{* *}$ Assoc. Prof. Dr. Borut Bratina, Institution/Affiliation: Faculty of Economics and Business, University of Maribor. Research fields: Corporate Law, Corporate Governance, Business Law.
} 
II. NEW CORPORATE INSTITUTIONS INTENDED FOR IMPROVEMENT OF CORPORATE GOVERNANCE

A. Directors and Officers Liability Insurance ....

B. Waiver and Settlement of Compensation Claims

C. Supervisory Board and Audit.

D. Internal Audit. 624

E. Other Novelties of ZGD-1I 625 III. SOME OF THE "NOT ADOPTED" IMPROVEMENT PROPOSITIONS 625 CONCLUSION 631

\section{INTRODUCTION}

In Slovenia, corporate law is governed mainly by the Companies Act (Official Gazette of the Republic of Slovenia, nos. 65/09-official consolidated text, 33/11, 91/11, 32/12, 57/12, 44/13 Const. Court's Decision and $82 / 13$, hereinafter referred to as: ZGD-1) which constitutes the basic organic law in the field of corporate law and lays down the basic rules for the establishment and operation of companies, sole proprietors, related persons, subsidiaries of foreign companies and their status restructuring (Article 1 of ZGD-1). After the implementation of ZGD-1 in 2006, eight amendments to the act have been adopted. The last time (prior to the latest amendment), ZGD-1 has been amended with the Act Amending the Companies Act (ZGD-1H, Official Gazette of the Republic of Slovenia, no. 82/13) that entered into force on October 9, 2013.

ZGD-1, as a so-called corporate constitution governing the operation of business entities in Slovenia, contains a number of mandatory and discretionary solutions that directly affect the development and functioning of corporate governance. Due to Slovenia's membership in EU, amendments to ZGD-1 are, naturally, determined also by the requirements of European legislation. Since the latest renewal of ZGD-1 is fairly extensive, all thematic fields that have been subject to modification are presented below, with a special attention given to the changes that will materially impact corporate governance in Slovenia. Because the legislator did not thoroughly follow the propositions presented by experts and practitioners, a selection of important corporate institutions that should be implemented de lege ferenda is also described.

\section{AMENDMENT ZGD-1I}

The latest amendment to ZGD-1 (ZGD-1I, Official Gazette of the Republic of Slovenia, no. 55/15 of July 24,2015 ) has affected the following 
areas:

1. Solutions related to harmonization with the Directive 2013/34/EU:

Thresholds for classification of corporations into micro, small, medium and large corporations have been adapted to Directive 2013/34/EU. The thresholds for micro corporations (annual net turnover of 70,000 EUR and a balance sheet total of 350,000 EUR) and small corporations (annual net turnover of 8,000,000 EUR and a balance sheet total of 4,000,000 EUR) have been lowered, while the threshold for medium corporations has been set higher (annual net turnover of 40,000,000 EUR and a balance sheet total of 20,000,000 EUR).

Provisions on the obligation to prepare consolidated annual financial statements, including the provisions on their form and content, have been implemented. The legislator has used the option to impose the obligation of preparing consolidated annual financial statements only on large groups. Corporations that are bound to prepare consolidated annual financial statements must use international accounting standards.

General rules on valuation of items in financial statements have been implemented. The basic rule is valuation in accordance with the historical cost. Companies are allowed to use alternative valuation methods and are permitted to value the tangible fixed assets according to the revalued amounts, while being able to valuate financial instruments and investment property according to their fair value. Small corporations that use the alternative valuation methods must present their annual financial statements to the auditor. The amendment also sets the basic rules for assets and liabilities related to recognition, measurement and valuation.

In accordance with the Directive, content of the notes to the financial statements has been prescribed. Disclosures in the notes to the financial statements depend on the size of the company. Small companies are not required to disclose more information than demanded by the Directive 2013/34/EU.

Simplifications for micro companies have been introduced. Micro companies are not required to prepare notes to the financial statements as defined by the law. Instead, disclosure of only certain information is necessary.

A requirement to prepare a report on payments to the governments has been implemented, including the provisions on the content of the report. The requirement relates to large companies performing activities involving exploration, prospection, discovery, development, and extraction of minerals, oil, natural gas deposits or logging of primary forests.

2. Solutions related to harmonization with the Directive 2014/56/EU: 
Provisions of the Directive relating to the content of the audit report have been implemented and additional requirements concerning the audit committee have been introduced.

3. Solutions related to implementation of the Regulation 1126/2008/EC:

All companies obliged to consolidate have to follow international accounting standards.

4. Solutions that relate to supplementation of arrangements governed by ZGD-1:

A new limitation as regards the establishment of business entities has been introduced. Namely, a person on whom a fine has been imposed twice in the last three years with a final decision issued by the Labour directorate of the Republic of Slovenia or by the Financial administration of the Republic of Slovenia for a minor offence related to remuneration for work or to undeclared work cannot become a founder, a company member or a sole proprietor. Additionally, the persons that have participated with more than $50 \%$ in the capital of a limited liability company that has been cancelled from the court register without liquidation in accordance with the provisions of the Financial Operations, Insolvency Proceedings and Compulsory Dissolution Act are also limited as regards establishing a new company. By upgrading the existing mechanisms the legislator wishes to restrict fraudulent business practises.

Amendment ZGD-1I also contains provisions that prevent chaining of companies. A general limitation regarding the establishment of limited liability companies has been implemented, stipulating that a person is allowed to establish only one company in a three-month period and to acquire a share in a limited liability company that is not older than three months. This provision aims at making the chaining of companies harder and at restricting the individuals from establishing limited liability companies to stock, consequently preventing illegal practices of defrauding the creditors, employees and the state. The measure of restraining the establishment of limited liability companies is not targeting the persons with fair business aspirations and is not intended for inhibiting the entrepreneurial initiative, which is why exceptions from the general prohibition have been included. Accordingly, the regime does not apply to medium and large enterprises (including banks, insurance companies and listed companies), to the Bank Assets Management Company (BAMC/DUTB) and in the cases where the share has been acquired in the course of restructuring. Additionally, the limitation regarding the establishment of limited liability companies is not applicable if all the companies in which the individual has acquired shares in the last three 
months are operating. According to ZGD-1, a company is operating if it holds a current account, has no outstanding tax obligations and has one employee employed part time for the duration of at least one month. If a person that meets all the above-mentioned preconditions has established a company in the past three months, the general limitation of one company per three months does not apply. ${ }^{1}$

Limitations regarding the establishment of companies will be automatically verified within the e-VEM (All in One Place) information system prior to the submission of the application for entry in the court register or in the Slovenian Business Register.

Further, the amendment prevents the founders and company members from using company's assets necessary for company's operation through a loan agreement concluded at the time of establishment. The goal of such arrangement is to secure that the company can dispose with the assets in the minimum amount of the subscribed capital (currently only 7,500 EUR) at any time in order to enable the company's unhindered operation and to ensure the protection of creditors. Loans to company members, directors and related persons will in such case not be deemed as company's assets. ${ }^{2}$

In order to improve corporate governance, specific new provisions have been incorporated into ZGD-1. The institution of internal audit has been introduced, providing for a certain level of independence of internal auditing service. Independence of such service is of the essence to ensure a faster discovery of possible deficiencies in the company's operation. The concept of independent internal audit should also enhance the efficiency of supervisory board's performance, especially of its audit committee. The latter one benefits more from internal audit if the above-described system is in place than in case where the internal auditor works exclusively in the sphere of management. Additionally, layout of D\&O insurance has been modified. In case an insurance contract is concluded, a deductible in the

\footnotetext{
${ }^{1}$ B. Bratina, Nova ureditev omejitve ustanavljanja družb in podjetnikov, pridobitve statusa družbenika ter prenehanja gospodarskih družb [New Arrangement of Limitations Regarding Establishment of Corporations and Sole Proprietors, Acquisition of Company Member Status and Termination of Corporations], 6-7 Podjetje in delo 1082 (2015). Also S. Prelić, Novelirani pravni instituti pri podjetnikih, osebnih družbah in družbah z omejeno odgovornostjo [Amended Legal Institutions Regarding Sole Proprietors, Partnerships and Limited Liability Companies], 6-7 Podjetje in delo 1107 (2015).

${ }^{2}$ Even before the amendments in the field of establishment and operation of business entities, the Slovenian regime was in many segments recognised as a role model. The latter results in Slovenia's positioning according to the "Doing Business" study. Slovenia has improved especially in the field of "ease of company establishment", moving up by 86 places since the year 2007 and holding the $14^{\text {th }}$ position in the year 2014. A big step forward has also been made in the field of cross-border business where, in 2014, Slovenia was ranked $52^{\text {nd }}$.
} 
amount of at least $10 \%$ of the damage needs to be agreed upon, however, it must not exceed 1.5 times the amount of the company's annual fixed income. In order to enhance corporate governance, the circle of companies that need to include a statement on corporate governance in their annual report has been expanded to the companies legally bound to auditing.

Additional requirements regarding related entities within a group of companies have been incorporated as well. Until now, ZGD-1 has not set out detailed rules on reporting on business agreements and on their audit. However, existing rules regarding delivery of information to shareholders within groups of companies have proven to be insufficient. Namely, shareholders will not be adequately informed on a certain business agreement prior to their vote on that agreement, if the text of the agreement is presented to them as late as during the general meeting where they have to cast their vote. Moreover, in the past, ZGD-1 did not require management to produce a report on business agreements and did not require the business agreements to be audited. As a consequence, amendment ZGD-1I includes an in-depth arrangement of the report on business agreements, on audit of the agreements and on the consent to concluding such agreements. Further, creditors' rights within groups of companies are thoroughly dealt with. Prior to ZGD-1I, the Companies Act included no detailed provisions on the role of the auditor as regards the report on relations with related entities and did not regulate the review of the dependency report by the supervisory board, which is why suitable modifications have been included in the amendment. The act now regulates the review of dependency report by the supervisory board, thereby increasing the transparency of relations between the controlled and controlling companies and increasing the efficiency of auditor's review, as well as the efficiency of the review of the report by the supervisory board. The importance of the dependency report is rising, with its informative function on one hand and even more significant preventive function on the other hand. Additionally, the act now entitles every shareholder or company member to request the court to appoint a special auditor who shall review the company's business relations with the controlling company or with a company related to it, however, only if certain cumulatively listed preconditions have been met. Since the dependency report is not published, the special auditor's report can serve as a basis for an action for damages. ${ }^{3}$

\footnotetext{
${ }^{3} \mathrm{P}$. Podgorelec, Podrobnejša pravila varstva upnikov in manjšinskih delničarjev v koncernskem pravu (povezane družbe in podjetniška pogodba) [Detailed Rules on the Protection of Creditors and Minority Shareholders in Corporate Group Law (Related Companies and the Business Agreement)]. 6-7 Podjetje in delo 1120 (2015).
} 
The amendment has also renovated the penal provisions by adding several new minor offences (e.g. relating to members of management, board of directors and supervisory board). A novelty is also that the amount of fine depends on the size of the company. Introduction of new minor offences has been driven by the practically confirmed finding that a norm, for which a corresponding minor offence is not enacted, presents lex imperfecta, because its violation is not adequately sanctioned.

\section{NEW CORPORATE INSTITUTIONS INTENDED FOR IMPROVEMENT OF CORPORATE GOVERNANCE}

A number of different modifications fall within the spectrum of novelties that aim at improving corporate governance as regards public limited companies, including alterations of balance sheet guidelines (the "accounting Directive") and amendments regarding categories of reserves, establishment, termination, mergers and divisions of corporations, (stricter) sanctioning of particular actions within the "penal provisions", however, the most important amendments introduced with ZGD-1I that directly affect corporate governance are the following corporate institutions.

\section{A. Directors and Officers Liability Insurance}

As to the system of liability of members of management and supervisory bodies in public limited companies, novelties relate mostly to the admissibility of D\&O liability insurance. D\&O liability insurance is a voluntary insurance taken out by the company on behalf of the members of its management and supervisory bodies, while the subject matter insured is personal liability of the members of company's management and supervisory bodies towards the company or third parties. In practice, such contractual relationship insures the company and (through the company) the members of its managerial and supervisory bodies, often including other high-level executives of the company or its subsidiary companies, where the company is simultaneously the entity seeking insurance (policy-holder) and the entity paying the insurance premium.

Since such form of insurance has been subject to a number of concerns raised by the experts, the wording of the amendment has been drafted correspondingly and requires the insurance contract to include a deductible amounting to a certain percentage of the damage (caused by the insured persons during the execution of their corporate functions within the company), which needs to be borne by the insured persons that have caused the damage. In ZGD-1, the deductible spans from minimum $10 \%$ of the 
caused damage to maximum 1,5 times the amount of the company's annual fixed income (Article 263/2 of ZGD-1). A similar provision can be found in $\S 93$ of German $\mathrm{AktG}^{4}$

The lower limit of the amount of the deductible is set cogently, while the upper limit presents a discretionary threshold. The decision on taking out the insurance is left to the company's complete discretion. ${ }^{5}$

\section{B. Waiver and Settlement of Compensation Claims}

Members of management and supervisory bodies are effectively protected from damage liability and are therefore not obliged to compensate the caused damage if their action is based on a decision adopted by the general meeting (Article 263/3 of ZGD-1). Yet, such regime does not apply to the members of management acting upon the approval of the supervisory or management board. In such case, the damage liability of management members is not excluded, however, the company can waive the claim for damages. Additionally, the claim can also be settled (ZGD-1 mistakenly uses the term "offset"), but not earlier than three years from the claim origination date.

To prevent the management from excessively interfering with the rights of minority shareholders, the amendment mandatorily requires the general meeting to agree with the waiver or settlement of the compensation claim, while also requiring a special statement (which needs to be incorporated into the minutes of the general meeting-Article 263/3 of ZGD-1) that the minority of shareholders (holding a minimum $10 \%$ of the share capital) do not oppose such decision. Such statement presents a conditio sine qua non for the waiver or settlement of compensation claims.

A company's compensation claim towards a member of its management or supervisory body can also be invoked by the creditors in case the company is unable to repay them (Article 263/4 of ZGD-1). With the amendment ZGD-1I, it is clearly defined that the company can waive or settle compensation claims, however, this must not be to the detriment of its creditors. In case the creditors are injured, waiver or settlement has no legal

\footnotetext{
${ }^{4}$ M. Kocbek, Novelirani instituti delniškega prava glede upravljalske in kapitalske strukture ter uveljavljanja pravic manjšinskih delničarjev in upnikov [Amended Institutions of Public Limited Company Law as Regards Management and Capital Structure and Exercising Rights of Minority Shareholders and Creditors], 6-7 Podjetje in delo 1066 (2015).

${ }^{5} \mathrm{M}$. Bratina, Zavarovalni primer pri zavarovanju odgovornosti članov organov vodenja in nadzora $v$ gospodarskih družbah (zavarovanje D\&O) [Contingency in the Sphere of Insurance of Liability of Members of Management and Supervisory Bodies of Corporations (D\&O Insurance)], 2 Podjetje in delo 294 (2011).
} 
effect, even though they are based on a lawful decision of the general meeting.

In case the company has been adjudicated bankrupt, the compensation claim can be filed on behalf of all the creditors that have the right to be repaid during the bankruptcy proceedings. In such case, the compensation must be paid to the company (the debtor in bankruptcy) who then distributes the bankruptcy estate amongst the creditors in accordance with the par condition creditorum principle. The compensation claim can be filed by the insolvency practitioner or by any creditor entitled to carry out procedural acts in bankruptcy proceedings (Article 263/5 of ZGD-1).

The amendment has (following the German example) ${ }^{6}$ established the 5 -year limitation period as the objective time limit (counting from the date when the damage was caused) for the limitation of compensation claims. Along with the general limitation period, the amendment has introduced special (10-year) limitation periods for companies over which the Republic of Slovenia or its self-governing local communities have a controlling influence. ${ }^{7}$ Such duality of limitation periods could be in certain cases questionable in terms of the constitutional principle of equality before the law.

\section{Supervisory Board and Audit}

The modification of ZGD-1 relates predominantly to the functioning of the supervisory board and to the attitude towards audit within the company. In that regard, the amendment stipulates the competences of the supervisory board related to appointing a so-called specific expert, concluding the contract with the auditor in relation with the annual report and consolidated financial statements etc. (Article 281 of ZGD-1). Audit committee's tasks have been redefined as well, while a special emphasis needs to be placed on the "special" conditions for becoming a member of the audit committee (Article 280 of ZGD-1). Namely, the law requires all the members of the audit committee to be independent from the audited entity. The members of the audit committee are most often members of the supervisory board, whereas one member should be an external expert proficient in audit or accounting. All other members of the audit committee must also be sufficiently qualified for holding such a demanding position, yet,

\footnotetext{
${ }^{6}$ Para. 6 of $\S 93$ AktG. See M. Kocbek, Op. Cit., at 1072.

${ }^{7}$ Controlling influence exists if the Republic of Slovenia or its self-governing local community, directly or indirectly through another public law entity, individually or jointly, holds a majority share of subscribed capital, majority of voting rights or the right to appoint or recall the majority of members of management or the supervisory board (Article 263/8 of ZGD-1).
} 
professionals from other fields of expertise may also be taken into account. The law offers no definition of "independence", which is why the term can be determined in accordance with the Management code for publicly traded companies-in case the company opts for the use of the Slovenian code, which is in its own discretion. Still, the question of relationship between independence of supervisory board members and the requirement of audit committee members to be independent remains open-ended, especially as regards the companies with the two-tier management system.

Due to harmonization with the Directive 2006/43/EC (and with the modifications included in the Directive 2014/56/EU) which sets up the institution of audit and the operation of audit committees, amendment ZGD1I stipulates that every corporation which is an object of public interest ${ }^{8}$ is obliged to form an audit committee (Article 279 of ZGD-1).

\section{Internal Audit}

The concept of internal audit is a complete novelty introduced with ZGD-1I. Since certain public limited companies with a two-tier management system have, in the course of their operation, autonomously formed internal audit services, a number of questions have arisen regarding the relations between the management, supervisory board and the general meeting as regards corporate governance. To clarify these questions, the amendment has introduced a facultative option of forming an internal audit service, including the rules for its operation, especially as regards the relationship between management and the supervisory board, focusing on internal audit's position within this relationship.

Internal audit service must annually prepare a report on its work, submitting it to management, the supervisory board ${ }^{9}$ and to the auditor of financial statements, no later than three months after the end of the business year (Article 281.a/1 of ZGD-1). Supervisory board gives consent to the appointment, dismissal and income of the head of internal audit, to the instrument defining the purpose and tasks of internal audit and to the annual work plan of the audit (Article 281.a/2 of ZGD-1). If internal audit is performed by external advisors, supervisory board gives consent to the conclusion, modification and termination of contracts with such advisors (Article 281.a/3 of ZGD-1). The supervisory board and its audit committee

\footnotetext{
${ }^{8}$ Object of public interest is a company whose securities are traded on the organized market, a credit institution as defined by law governing banking or an insurance company as defined by law governing insurance operations (Article 53/4 of ZGD-1).

${ }_{9}$ It needs to be clearly pointed out that in a one-tier management system the role of supervisory board is assumed by the company's management board.
} 
may require the internal audit service to provide them with supplementary information, in addition to the information included in the annual report on internal audit.

\section{E. Other Novelties of ZGD-1I}

Amongst other novelties that affect corporate governance within public limited companies, the following institutions need to be pointed out:

- Supervisory board's specific expert (Article 281/2 of ZGD-1) who can exercise certain rights related to the insight into company's documentation;

- Special competence of the supervisory board's president to represent the company in certain cases (Article 281/2 of ZGD-1)-concluding contracts with specific experts or auditors;

- Payments to the members of supervisory board's committees (especially to their external members), where the amendment indicates the supervisory board as the competent body (Article 279/3 of ZGD-1);

- Determination of procurator's powers as regards representation of the company in court or in front of other authorities (Article 35/3 of ZGD-1);

- Modification of certain rules on corporate group law;

- Tightening the minor offence sanctions for violations of ZGD-1.

\section{SOME OF THE "NOT ADOPTED” IMPROVEMENT PROPOSITIONS}

Unfortunately, Slovenian legislator did not follow the doctrinal findings in the field of corporate law and did not fully consider national and foreign case law, thus failing to take into account the position that every action of the members of management and supervisory bodies should be assessed in accordance with the business judgment rule. Such position has been decisively adopted by both Slovenian legal theory ${ }^{10}$ and case law ${ }^{11}$. Supreme Court of the Republic of Slovenia has, in the decision no. III Ips $80 / 2010$ of 9 July 2013, expressly underlined that

$\ldots$ the theory, relying on the comparative law doctrine, is unanimous that assessment of management's decisions in the situation at hand requires ex ante

\footnotetext{
${ }^{10}$ B. Bratina, D. Jovanovič, M. Bratina, Pojem in pomen uzakonitve pravila podjetniške presoje-več kot le kozmetična sprememba [Notion and Purpose of Enactment of Business Judgement Rule-More than Just a Cosmetic Modification], 9 Pravna praksa 22 (2015). Also P. Podgorelec, Odškodninska odgovornost članov poslovodstva - analiza nekaterih sodb Vrhovnega sodišča RS [Damage Liability of Management Members-Analysis of Particular Judgements of the Supreme Court of the Republic of Slovenia], 5 Podjetje in delo 763 (2013).

${ }^{11}$ Supreme Court of the Republic of Slovenia, decision No. III Ips 80/2010 of July 9, 2013; Higher Court of Ljubljana, decision No. I Cpg 171/2012 of October 10, 2013.
} 
consideration of facts of the case. This means that the state the managers were in at the moment of taking the decision, when the actual effects of the decisions were still uncertain, needs to be borne in mind. Namely, managerial decisions are based on presumptions and prognoses that allow the assessment of future developments only to a certain extent or do not allow it at all. It should not be neglected that the information on possible alternatives to their decisions is accessible to the members of management only to a limited extent; information on suitability of different decisions-if there are multiple possible decisions at all-is generally not available to the extent that would enable a complete comparison of the alternatives. Usually, the information becomes available only after the decision has already been taken. For the mistakes of this kind the managers cannot be held liable, if they acted diligently enough when they took the decision; otherwise, they would be held liable for something that is beyond their control.

In general, the goal of management bodies (and indirectly also of supervisory bodies) is company's good business performance, its development and profit-making, whereby the interests of various stakeholders also need to be kept in mind. To follow these goals, members of management bodies need to take decisions on a daily basis. Many of those decisions carry certain risks and it can often happen that the members of management bodies do not have a "lucky hand" when taking the decision. It would be completely wrong if the members of management bodies were liable for a business failure. ${ }^{12}$ This is the exact purpose of the business judgement rule which is used to separate negligent conduct from unsuccessful business manoeuvres. This is especially important in the time of crisis, when the factors that affect the success of a certain decision are particularly numerous, while the members of management bodies have no influence on these factors. For the business judgment rule to become effective and to ensure the member of the management body a margin of discretion, particular preconditions have to be met-the decision must be business related, it must be based on appropriate information and it must be made to the benefit of the company. Additionally, the decision must be made outside the sphere of conflict of interests or decision-maker's personal interests. ${ }^{13}$ In case a conflict of interests exists, it must be resolved using generally accepted good practices of corporate government (e.g. by exclusion from discussion and voting or by abstaining from voting).

\footnotetext{
${ }^{12}$ G. Spindler, in W. Goette, M. Habersack, S. Kalss, Münchener Kommentar zum Aktiengesetz [Münchener Commentary to Corporation Act $(A k t G)$ ]. 5 (C. H. Beck, München, commentary to Article 93 2014).

${ }^{13} \mathrm{~J}$. Gehb, M. Heckelmann, Haftungsfreistellung von Vorständen [Indemnification of Directors], Zeitschrift für Rechtspolitik 145 (2005). See also G. Spindler, in W. Goette, M. Habersack, S. Kalss, Op. Cit., at 47.
} 
In practice, business judgement rule presents the circumstances in which it can be deemed that the prescribed level of diligence has been satisfied and that further assessment is not necessary. However, it cannot be simply presumed that the prescribed diligence has been violated if the preconditions for the business judgement rule protections have not been met. In such case the court still needs to assess whether the member of management or supervisory body has acted in accordance with the prescribed level of diligence. $^{14}$

The purpose of business judgment rule is particularly to prevent the occurrence of hindsight bias. The latter was already described in the above cited decision of the Supreme Court of the Republic of Slovenia which ruled that the state the managers were in at the moment of decision-taking, when the actual effects of the decisions were still uncertain, needs to be borne in mind. ${ }^{15}$ In case of court proceedings, this means that the court's decision could be obscured by the results of the management's decision, the bad results contaminating also the decision-making process, even though the latter was carried out in a completely appropriate manner. ${ }^{16}$

In addition to Slovenian case law, certain decisions of German courts also need to be pointed out. Constitutional Court of the Federal Republic of Germany has (in its decision no. 2 BvR 2559/08 of June 23, 2010) clearly alerted to the immensely broad margin for manoeuvre left to the members of management and supervisory bodies, obliging them to take risky decisions, which is why the fact that a certain decision was not successful does not allow for a conclusion that the conduct was wrongful or unlawful (see also the decision of the Supreme Court of the Federal Republic of Germany, no. 1 StR 280/99 of April 6, 2000, where the court distinctly set very high standards for assessment of professional diligence by a criminal court and alerted to possible differences in liability of individual perpetrators-in accordance with the corporate effect). In cases no. 1 StR 280/99 of April 6, 2000 and no. 1 StR 185/01 of November 15, 2001, the Supreme Court of the Federal Republic of Germany has pointed out that the violation of due diligence cannot be asserted solely because the risk of a certain business has materialised. Additionally, the court has emphasized that ex post assessment

\footnotetext{
${ }^{14}$ Ibidem.

${ }^{15}$ D. KAhNEman, Thinking, FAST AND Slow 203 (New York: Farrar, Straus and Giroux 2011).

${ }^{16} \mathrm{~J}$. Koch, in U. Hüffer, Aktiengesetz kommentar [Commentary to Corporation Act (AktG)], 8 (C. H. Beck, München, commentary to Article 93, 2014). Explicitly about this occurrence (ger. Rückschaufehler) Brömmelmeyer, C. Neue Regeln für die Binnenhaftung des Vorstands-Ein Beitrag zur Konkretisierung der Business Judgement Rule [New Rules on the Liability of Management-a Contribution to the Concretization of the Business Judgment Rule]. Zeitschrift für Wirtschafts-und Bankrecht, 2065 (2015).
} 
of conduct is not allowed (due to the above-mentioned hindsight bias). The court must therefore take into account all the elements of diligence imposed on the members of management and supervisory bodies, along with the rules of business judgement.

It is fundamental to call attention also to the decision of the Constitutional Court of the Republic of Slovenia ${ }^{17}$ which indicates that the court must, in every particular case, answer the question whether the individual has abused its powers while performing the business activity, taking into account the assessment in accordance with the corporate law instruments regulating the area within which the individual has presumably acted unlawfully-thus directly including the business judgement rule, clearly adopted by Slovenian case law ${ }^{18}$. There is no doubt that, in accordance with the position of the Constitutional Court of the Republic of Slovenia, certain room for manoeuvre must be taken into account as regards making business decisions (also called business judgement) when assessing the existence of statutory elements of economic criminal offences as well. Therefore, when the court weights whether particular conduct was diligent enough or not, the assessment must be made in accordance with the rules of corporate law. It shall not be forgotten that the above-mentioned room for manoeuvre is imperative for the members of management and supervisory bodies to be able to take decisions at all.

It must also be taken into account that decision-making in business includes a particular level of unpredictability and risk by its very nature; The decisions are always uncertain to a certain extent (see also the decisions of the Supreme Court of the Federal Republic of Germany, no. 1 StR 280/99 of April 6, 2000 and no. 1 StR 185/01 of November 15, 2001). ${ }^{19}$ With these decisions there is no "right" or "wrong"- there is always a choice between at least two potentially right decisions.

An element of the business judgement rule is also the requirement for

\footnotetext{
${ }^{17}$ Decision of the Constitutional Court of the Republic of Slovenia, No. U-I-268/05 of 5 July 2007.

${ }^{18}$ P. Podgorelec, Op. Cit., at 763 (2013).

${ }^{19}$ M. Kock, R. Dinkel, Die zivilrechtliche Haftung von Vorständen für unternehmerische Entscheidungen-Die geplante Kodifizierung der Business Judgement Rule im Gesetz zur Unternehmensintegrität und Modernisierung des Anfechtungsrechts [The civil liability of directors for business decisions - The planned codification of business judgment rule in the Act on Corporate Integrity and Modernization of the Right to Appeal], Neue Zeitschrift für Gesellschaftsrecht 441 (2014); G. Hoor, Die Präzisierung der Sorgfaltsanforderungen nach \$ 93 Abs. 1 Aktg durch den Entwurf des UMAG [The Clarification of the Diligence Requirements in Accordance with \$ 93 Para. 1 AktG by the Draft of UMAG]. Zeitschrift für das Deutsche Steuerrecht 2014 (2004). See also P. Preussner, Risikomanagement und straffrechtliche Verantwortung-Corporate Governance am Beispiel der Kreditwirtschaft [Risk Management and Criminal Responsibility-Corporate Governance on the Example of the Banking Industry], BKR 347 (2004).
} 
the decision to be made to the benefit of the company (the term "company's interest" would probably be more appropriate, yet, in this article we will use the initial wording). The answer to the question what exactly is "to the benefit of the company" is far from simple. If we look upon the explanation given by the German legislator that was followed when preparing ZGD-1, we find out that "to the benefit of the company" are those actions that contribute to the long term strengthening of the company's business success, its competitive position, its products or services, whereby the actions that are made to the benefit of subsidiary companies or to the benefit of the group of companies are also to be taken into account. ${ }^{20}$ It is important to interpret group companies as a single company (benefits of the group of companies are to be interpreted as the benefits of one economic unit) and to assess the decisions of management and supervisory bodies accordingly. Ambiguity of this element has an impact on a number of stakeholders whose interests can be affected with a decision of the management or supervisory body. ${ }^{21}$ However, particular conduct is not deemed to be made to the detriment of the company only due to the fact that certain risk was taken, since this is a part of decision-making. In the well-known case ARAG/Garmenbeck ${ }^{22}$ which presents the basis for the use of business judgement rule in the German legal area, the Supreme Court of the Republic of Germany has clearly stated that the risk must be completely mis-assessed for the conduct to be determined as unreasonable. Members of management and supervisory bodies have certain room for maneuver, yet, they have to be aware that their decision must not be based on the interests of a particular stakeholder; e.g. of a group of shareholders. Still, more important than the definition of what conduct is made to the benefit of the company is the fact that this conduct must not be based on a conflict or interests or on personal interests of the decision-maker. ${ }^{23}$ If the decision is economically founded and is taken in accordance with the business plans, conduct was certainly made to the benefit of the company. ${ }^{24}$ Let us point out once again that the

\footnotetext{
${ }^{20}$ Entwurf eines Gesetzes zur Unternehmensintegrität und Modernisierung des Anfechtungsrechts (UMAG) [Draft Law on Corporate Integrity and Modernization of the Right to Appeal], (14 March 2005), http://dip21.bundestag.de/dip21/btd/15/050/1505092.pdf (last visit Feb. 2, 2015).

${ }^{21}$ J. Gehb, M. Heckelmann, Op. Cit., at 145.

${ }^{22}$ II ZR 175/95 of April 21, 1997.

${ }^{23}$ G. Spindler, Op. Cit., at 47 (commentary to Article 93); S. Blasche, Die Anwendung der Business Judgement Rule bei Kollegialentscheidungen und Vorliegen eines Interessenkonflikts bei einem der Vorstandsmitglieder [The Application of the Business Judgment Rule in Collegiate Decisions and Conflict of Interest with One of the Board Members], Die Aktiengesellschaft, 692 (2010).

${ }^{24}$ A. Isola, D. Seidl, F. Sprajc, Auswirkungen des "Styrian Spirit"-Urteils des OGH auf die Gewährung von Sanierungskrediten? [Effects of the "Styrian Spirit"-Judgement of the Supreme Court on Granting the Rehabilitation Loans?], 3 Der Gesellschafter 172 (2014).
} 
result of the evaluated conduct is not legally relevant for the assessment of diligence.

It should also be taken into consideration that all decisions must be made on the basis of appropriate information. Appropriateness of information is assessed on two levels-first, it needs to be evaluated whether the decision was taken on the basis of essential relevant information related to the particular decision (objective criterion). If the answer is positive, the subjective element does not have to be evaluated-that is whether the member of the management or supervisory body could believe or trust those information (subjective criterion), since he made a decision on the basis of (almost) all available relevant information. However, if the objective criterion is not satisfied, subjective criterion has to be used. The subjective element does not encompass all objectively accessible information, but only information that could be rated as appropriate by the member of the management or supervisory body at the given moment, in accordance with required diligence. ${ }^{25}$ A room for manoeuvre is given to the decision-maker to evaluate which information is relevant in a particular case-it is crucial to consider the decision-maker's perspective. ${ }^{26}$ It thus needs to be taken into account that the information that is appropriate in one case can be considered inappropriate or insufficient in another case; e.g. due to the deadline for taking a particular decision or due to the decision's importance. ${ }^{27}$ The more important the decision, the more conclusive information the decision is based on must be to satisfy the subjective criterion. $^{28}$

In addition to all the above-mentioned court decisions, let us stress also the decision of the Regional Court in Hamburg, no. 608 KLs 12/11 of July 9, 2014, which indicates that conduct can be considered unlawful in terms of Article 266 of StGB (i.e. Article 240 of KZ-1) only if the violation is substantial, meaning that it must be evident. Any other conduct is not sufficient to constitute the unlawful action described under Article 266 StGB.

\footnotetext{
${ }^{25}$ G. Spindler, Op. Cit., at 48 (commentary to Article 93); M. Kock, R. Dinkel, Op. Cit., at 441; D. Weber-Rey, J. Buckel, Best Practice Empfehlungen des Deutschen Corporate Governance Kodex und die Business Judgement Rule [Best Practice Recommendations of the German Corporate Governance Code and the Business Judgment Rule], Die Aktiengesellschaft 845 (2011).

${ }^{26}$ This can be derived from the decision of the Supreme Court of the Federal Republic of Germany, no. II ZR 202/07 of July 14, 2008; See also J. Koch, in U. Hüffer, Op. Cit., at 21 (commentary to Article 93).

${ }^{27}$ See also M. Kock, R. Dinkel, Op. Cit., at 441.

${ }^{28}$ Ibidem.
} 


\section{CONCLUSION}

With the amendment ZGD-1I, Republic of Slovenia has followed the crucial findings of legal theory and case law in the field of corporate law (with some exceptions), while also comply with all the guidelines and recommendations adopted on the EU level. Doing so, the state has demonstrably made a step towards modernisation and improvement of corporate legislation, also with a goal of improving corporate governance. Nevertheless, besides all the novelties and sensible adjustments, it can still be concluded that all modifications have not been sufficiently thought through and will possibly cause significant problems in practice, which this article also alerts to. 